\title{
KESADARAN PENDIDIKAN; KUNCI PENGEMBANGAN PENDIDIKAN ISLAM
}

\author{
M. Wafiyul Ahdi, SH., M.Pd.I. \\ Dosen UNWAHA Jombang \\ Fakultas Agama Islam \\ Prodi PBA
}

\begin{abstract}
Abstrak
Manusia secara naluriah memiliki potensi intelektual dalam bidang afektif, kognitif dan psikomotorik yang bisa dikembangkan untuk meningkatkan kualitasnya melalui proses pendidikan. Macam-macam kesadaran pendidikan itu berupa dapat dilihat dari segi alur tahap pelaksanaan pendidikan, dari segi sasaran bimbimgan, dari segi sudut pelaku, dari fungsi kesadaran pendidikan, atau Mekanisme membudayakan kesadaran pendidikan. Tahap-tahap yang ditempuh untuk membudayakan kesadarn pendidikan, antara lain; Membentuk mindset, Mendemonstrasikan dan mendalami model sebgai contoh, Melaksakan kesadaran pendidikan secara realistis dalam tugas/wilayah kerja masing-masing komponen masyarakat, Mempublikasikan dan mempopulerkan hasil dan dampak kesadaran pendidikan untuk memberikan pengaruh dalam membudayakan kesadaran pendidikan, Melakukan evaluasi kritis terhadap semua tahapan-tahapan diatas, secara rasional, obyektif, kritis dan membandingkan dengan kondisi sebelumnya, Melakukan tindak lanjut dari hasil evaluasi.
\end{abstract}

Kata kunci : Kesadaran Pendidikan, Pendidikan Islam

Pendidikan adalah usaha sadar untuk menyiapkan peserta didik melalui kegiatan bimbingan, pengajaran, dan latihan dalam peranannya di masa yang akan datang (Hasbullah, 2012: 4). Pendidikan merupakan salah satu faktor penentu keberhasilan sebuah negara yang memiliki peranan penting dalam meningkatkan kualitas sebuah bangsa. Semakin banyak masyarakat terdidik suatu bangsa dan semakin tinggi tingkat pendidikannya maka hal itu mencermin kan kualitas sumber daya manusia bangsa tersebut.

Menurut Athiyah Al-Abrasy, pendidikan Islam adalah mempersiapkan manusia supaya hidup dengan sempurna dan bahagia, mencintai tanah air, tegap 


\section{Wafiyul Ahdi, SH., M.Pd.I.}

jasmaninya, sempurna budi pekertinya, pola pikirnya teratur dengan rapi, perasaannya halus, profesiaonal dalam bekerja dan manis tutur sapanya. Sedang Ahmad D. Marimba memberikan pengertian bahwa pendidikan Islam adalah bimbingan jasmani dan rohani berdasarkan hukum-hukum islam menuju kepada terbentuknya kepribadian utama menurut ukuran-ukuran Islam.

Sebagaimana diketahui bawa manusia itu sering kali disebut animal rasionale atau hayawan an natiq, yaitu makhluk yang memiliki potensi kejiwaan intelektual. Manusia memiliki potensi kognitif, afektif dan psikomotorik. Manusia pula lah makhluk yang memiliki unsur akal, hati, nafsu sahwat, nafsu amarah, roh dan nyawa. ${ }^{1}$ Sigmun Freud menyatakan bahwa manusia memiliki kepribadian yang terdiri dari tiga system pokok, yaitu id, ego dan super ego yang masing-masing bagian tersebut memiliki fungsi, sifat, komponen, prinsip kerja, dinamisme dan mekanisme tersendiri namun mempunyai abstraksi yang begitu erat satu sama lain sehingga tidak mungkin dipisahkan. ${ }^{2}$ Melihat struktur kejiwaan yang dimiliki manusia diatas, maka manusia memiliki kesempatan besar untuk mengembangkan potensi yang dimilikinya sehingga menjadi makhluk yang terpelajar dan unggul. Maka layaklah manusia diangkat oleh Alloh swt sebagai khalifah dimuka bumi mengalahkan makhluk alloh yang lain. Nabi Adam as bisa membuktikan keunggulan dan kelayakkannya menjadi khalifah Alloh setelah beliau bisa menjawab semua

\footnotetext{
${ }^{1}$ Abuddin Nata, Prespektif Islam tentang strategi pemebelajaran, Jakarta : Kencana, 2011, hal. 64.

2 Ibid, hal. 65.
} 


\section{Kesadaran Pendidikan; Kunci Pengembangan Pendidikan Islam}

pertanyaan yang diajukan oleh Malaikat. Nabi Adam memiliki ilmu pengetahuan yang dengannya Nabi Adam diangkat derajatnya oleh alloh swt.

Akan tetapi tidak sepenuhnya potensi yang dimiliki manusia tersebut bisa dikembangkan dengan baik. Menjadi manusia pembelajar yang selalu mengasah akal dan intelektualitasnya menjadi berkurang karena banyak factor yang menjadi penyebabnya. Salah satunya karena rendahnya kesadaran belajar manusia. Menusia lebih memilih sesuatu yang instan dan tidak mau berproses. Lebih memilih menikmati segala fasilitas yang memanjakannya daripada menempuh tahapantahapan pembelajaran yang berliku. Menurut Dalyono (2008), rendahnya minat terhadap pendidikan disebabkan oleh beberapa faktor, misalnya faktor pribadi (tingkat kesadaran), faktor ekonomi, faktor sosial budaya (social cultur), dan faktor letak geografis sekolah atau pusat pembelajaran. Penelitian Firdaus (2005) menyebutkan bahwa rendahnya minat orang tua untuk melanjutkan pendidikan anaknya ke Sekolah Menengah Pertama disebabkan: Pertama, faktor sosial budaya sebesar $87,3 \%$. Kedua, faktor kurangnya biaya pendidikan (ekonomi tidak mampu) diperoleh sebesar $86,0 \%$. Ketiga, faktor kurangnya tingkat kesadaran orang tua akan pentingnya pendidikan (faktor orang tua) diperoleh sebesar 59,1\%. Keempat, letak geografis sekolah sebesar 50,8\%.3 Selain itu modernisasi, globalisasi dan kapitalisasi pendidikan disinyalir ikut menjadi penyebab menurunnya kesadaran pendidikan masyarakat. Karena hal itu menjadikan pergeseran orientasi masyarakat dalam

3 Lihat http://ipahipeh.blog.fisip.uns.ac.id/2010/12/30/faktor-rendahhnya-kesadaran-masyarakat-mengenaipendidikan-formal/ 


\section{Wafiyul Ahdi, SH., M.Pd.I.}

pendidikan, menjadi materialistic dan mengesampingkan proses pembudayaan pembelajaran masyarakat yang ideal moralistic.

\section{Potensi Intelektual Manusia}

Menurut Quraish Shihab, ada tiga kata/istilah yang digunakan Al Qur'an dalam membicarakan manusia. Yaitu istilah yang insan / nas / ins, Basyar dan Bani Adam / Dzurriyah Adam. ${ }^{4}$ Manusia yang disebut sebagai insan selalu dikaitkan dengan kegiatan manusia yang amat luas yang terletak pada kemampuan menggunakan akalnya serta dalam mewujudkan pengetahuan konseptualnya dalam kehidupan kongkret. Pengertian ini menunjukkan pada kegiatan kebudayaan yang bersumber pada kapasitas akalnya yang tumbuh berkembang dalam kegiatan belajar ${ }^{5}$. Sedangkan manusia disebut dengan istilah Basyar, mengandung penertian bahwa manusia melakukan aktifitas lahiriyah yang dipengaruhi oleh kodrat alami. Melalui aktifitas tubuhnya, gagasan dan pemikiran manusia dapat diwujudkan dalam bentuk kongkrit, yaitu bentuk bentuk sebagai hasil karya dan cipta manusia yang memenuhi ruang tertentu, dapat diraba dan di foto, seperti lukisan, tarian dan kegiatan mengolah besi pada industry logam6. Sedangkan disebut sebagai bani Adam / Dzuriyah Adam, menunjukkan bahwa manusia adalah makhluk social yang dapat melakukan aktifitas social bersama-sama, seperti melakukan komunikasi social,

\footnotetext{
${ }^{4}$ M. Quraish Shihab, Wawasan Al qur'an : Tafsir Maudhu'I atas pelbagai persoalan umat, Bandung : Mizan, 1998, hal 278.

${ }^{5}$ Musa Asy'ari, Manusia Pembentuk Kebudayaan dalam al Qur'an, Yogyakarta : Lembaga studi filsafat islam, 1992, hal. 31

${ }^{6}$ Ibid, hal. 34
} 


\section{Kesadaran Pendidikan; Kunci Pengembangan Pendidikan Islam}

pemanfaatan sumber daya alam, menggunakan fasilitas social dan lain sebagainya. ${ }^{7}$ Dari keterangan tersebut bisa dipahami bahwa manusia memiliki dimensi insaniyah (akal/rasional), dimensi basyariyah (beraktifitas fisik) dan dimensi social sebagai bagian dari manusia yang lain.

Sebagaimana diketahui bahwa manusia adalah makhluk yang memiliki kemampuan intelektual sehingga ia dapat menerima pelajaran dari Tuhan. Informasi tentang manusia sebagai makhluk intelektual ini disebut sebagai aspek kognitif manusia. Aspek kognitif ini menjadikan manusia memiliki ketrampulan berpikir dalam rangka memperoleh pengetahuan. Menurut S. Bloom, aspek kognitif manusia terdiri dari enam komponen ketrampilan berpikir yang sifatnya hirarkis, yaitu :

1. Pengetahuan. Pengajaran pada aspek pengetahuan ini bertujuan untuk mencapai kemampuan ingatan manusia tentang hal-hal yang sudah dipelajari dan tersimpan dalam ingatanyang berkenaan dengan fakta, peristiwa, pengertian, kaidah, teori, prinsip dan metode.

2. Pemahaman. Pengajaran pada aspek ini bertujuan untuk mencapai kemampuanmenangkap arti dan maknatentang hal-hal yang dipelajari.

3. Penerapan. Pangajaraan pada spek ini bertujuan untuk mencapai kemampuan menerapkan metode dan kaidah untuk menghadapi masalah baru dan nyata.

\footnotetext{
${ }^{7}$ Ibid.
} 


\section{Wafiyul Ahdi, SH., M.Pd.I.}

4. Analisis. Pengajaran pada aspek ini bertujuan untuk mencapai kemampuan memerinci suatu kesatuan kedalam bagian bagian sehingga terstruktur keseluruhan dapat dipahami dengan baik.

5. Sintesis. Pengajaran pada aspek ini bertujuan untuk mencapai kemampuan membentuk pola baru, misalnya kemampuan menyusun program kerja.

6. Evaluasi. Pengajaran pada aspek ini bertujuan untuk mencapai kemampuan membentuk pendapat tentang beberapa hal berdasarkan criteria tertentu. Misalnya kemampuan menilai karangan orang lain. ${ }^{8}$

Selain aspek kognitif yang dimiliki oleh manusia, dia juga memiliki kemampuan untuk menghayati dan menyadari tentang berbagai hal yang diketahuinya yang mendorong dirinya melakukan aktifitas aktifitas lahiriyah. Dan hal ini disebut sebagai aspek Afektif. Menurut para ahli pada aspek kognitif ini terdpat lima keterampilan menghayati dan menyadari manusia, yang meliputi.

1) Penerimaan. Pengajaran pada aspek ini bertujuan untuk menumbuhkan kepekaan terhadap hal - hal tertentu, dan kesediannya untuk memperhatikan hal - hal tersebut. Misalnya mengakui adanya perbedaan.

2) Partisipasin. Pengajaran pada aspek ini bertujuan untuk menumbuhkan ketelaan, kesediaan mempraktikkan dan partisipsasi dalam kegiatan. Misalnya, mematuhi aturan dan berpartisipasi dalam suatu kegiatan.

${ }^{8}$ Sudirman, Ilmu Penidikan, Bandung : Remaja Rosdakarya, 1986, hal. 78-90 
3) Penilaian dan penentuan sikap. Pengajaran pada aspek ini bertujuan untuk menumbuhkan sikap menerima suatu nilai, menghargai, mengakui, dan menentukan sikap. Misalnya, menerima pendapat orang lain.

4) Organisasi - pengajaran pada aspek ini bertujuan untuk menumbuhkan kemampuan membentuk suatu system nilai sebagai pedoman dan pegangan hidup. Misalnya menempatkan nilai dalam suatu skala nilai dan menjadikannya sebagai pedoman dalam bertindak secara bertanggung jawab.

5) Pembentukan Pola Hidup. Pengajaran pada aspek ini bertujuan untuk menumbuhkan kemampuan menghayati nilai dan membentuknya menjadi pola nilai kehidupan pribadi. Misalnya, kemampuan mempertimbangkan dan menunjukkan tindakan yang disiplin. ${ }^{9}$

Potensi yang terkandung dalam diri manusia selanjutnya adalah psikomotorik yang pada dasarnya merupakan aspek keterampilan dan mempraktikan sebuah konsep yang telah dipahami dan dihayati. Menurut Simpson, bahwa aspek psikomotorik manusia ini terdiri dari tujuan perilaku sebagai berikut.

1) Persepsi. Pengajaran pada aspek ini bertujuan menggali, menumbuhkan, mengarahkan dan mengembangkan kemampuan memilah-milah (mendeskriminasikan) hal-hal secara khas, serta menyadari adanya perbedaan.misalnya pemilihan terhadap warna, angka dan sebagainya

\footnotetext{
${ }^{9}$ Ibid. hal. 96
} 


\section{Wafiyul Ahdi, SH., M.Pd.I.}

2) Kesiapan. Pengajaran pada aspek ini bertujuan menggali, menumbuhkan, mengarahkan, an mengembangkan kemampuan menemptkan diri dalam keadaan dimana akan terjadi suatu gerakan atau rangkaian tindakan yang mencakup jasmani dan rohani. Misalnya, menentukan posisi mulai berlari dalam suatu perlombaan.

3) Gerak terbimbing. Pengajaran pada aspek ini bertujuan menggali, menumbuhkan, mengarahkan, dan mengembangkan kemampuan dalam melakukan gerakan sesuai dengan contoh atau gerakan penerimaan. Misalnya, gerakan yang meniru tarian, membuat lingkaran sesuai pola, dan sebagainya.

4) Gerak yang Terbiasa. Pengajaran pada aspek ini bertujuan untuk menggali, menumbuhkan, mengarahkan dan mengembangkan kemampuan dalam melakukan gerak tanpa diberikan contoh terlebih dahulu. Misalnya, melakukan lompat tinggi dengan tepat.

5) Gerakan Kompleks. Pengajaran pada aspek ini bertujuan menggali, menumbuhkan, mengarahkan, dan mengembangkan kemampuan dalam melakukan gerakan atau keterampilan yang terdiri dari banyak tahap secara lancer, efisien, dan tepat.

6) Penyesuaian Pola Gerakan. Pengajaran pada aspek ini bertujuan menggali,menumbuhkan, mengarahkan dan mengembangkan kemampuan mengadakan perubahan dan penyesuaian pola gerakgerik dengan persyaratan khusus yang berlaku. Misalnya, kemampuan dalam bertanding dan berlomba. 
Kesadaran Pendidikan; Kunci Pengembangan Pendidikan Islam

7) Kreatifias. Pengajaran pada aspek ini bertujuan untuk menggali, menumbuhkan,mengarahkan dan mengembangkan kemampuan dalam melahirka pola gerakan gerakan baru atas dasar prakarsa sendiri. Misalnya, kemampuan membuat tari kreasi baru. ${ }^{10}$

Berbagai keterampilan pada aspek kognitif, afektif, dan psikomotorik tersebut pada intinya adalah merupakan pelaksanaan berbagai potensi manusia sebagai makhluk yang dapat berpikir, belajar, berbudaya dan berkreasi sebagai tersebut di atas.

Kemampuan manusia pada ketiga aspek tersebut sesungguhnya, dapat dijumpa dalam isyarat yang terdapat di dalam al qur an. Seperti yang tersirat dalam QS An Nahl : 78 berikut ini :

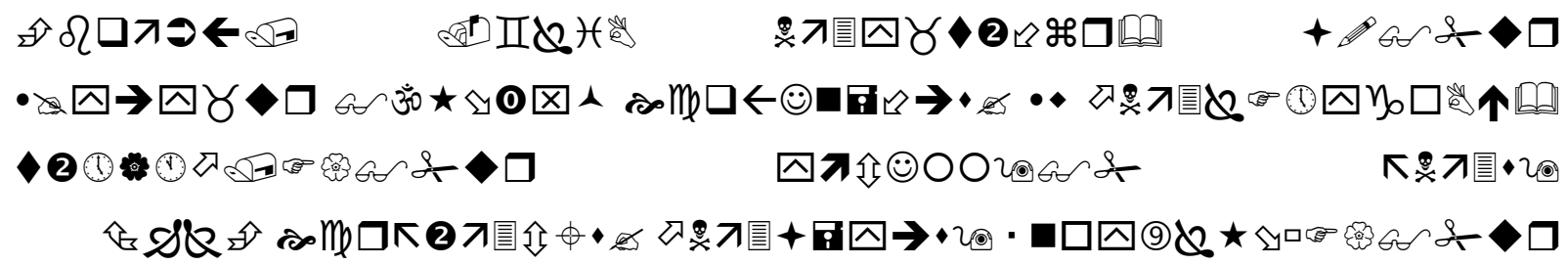

Artinya: Dan Allah mengeluarkan kamu dari perut ibumu dalam Keadaan tidak mengetahui sesuatupun, dan Dia memberi kamu pendengaran, penglihatan dan hati, agar kamu bersyukur. (QS. Al- Nahl,16:78).

Pada ayat tersebutt terdapat kata al- sama' (pendengaran) yang dapat diartikan aaspek psikomotorik, karena pendengaran terkait dengan salah satu pancaindra manusia yang paling berperan dalam kegiatan pembelajaran; kata albasher (penglihatan) yang dapat diartikan aspek kognitif, karena penglihatan dalam arti pemahaman terkait dalam salah satu unsur emikiran manusia; dan kata al-

\footnotetext{
${ }^{10}$ Ibid. hal. 99-100.
} 


\section{Wafiyul Ahdi, SH., M.Pd.I.}

af'idah (hati) yang dapat diartikan aspek afektif, karena hati terkait dengan salah satu unsure afektif. Selanjutnya, ketiga kata tersebut dihubungkan dengan kata sebelumnya yakni la ta'muna syaia (tidak mengetahui sesuatupun). ${ }^{11}$ hal ini menunjukan bahwa sebelum diberikan pendidikan, ketiga potensi yang dimiliki manusia tersebut tidak mengetahui segala sesuatu. Namun, setelah ketiga potensi tersebut di didik dan diajar dengan berbagai pengetahuan, keterampilan dan sebagainya melalui kegiata pembelajaran, maka manusia menjadi mengetahui segala sesuatu. Dengan demikian, bahwa pada diri manusia terdapat unsur kognitif, afektif, dan psikomotorik sejalan dengan pendapat para ahli.

\section{Macam-macam kesadaran pendidikan}

Secara etimologis, kesadaran berarti (1) keinsyafan, keadaan mengerti, seperti kesadaran akan harga dirinya timbul karena ia diperlakukan secara tidak adil; (2) hal yang dirasakan atau dialami seseorang, seperti kesadaran diri, keadaan seseorang atas keadaan dirinya sendiri ${ }^{12}$ Secara terminologis, kesadaran dapat diartikan sebagai timbulnya sikap, mengetahui, memahami, menginsafi, dan menundak lanjuti suatu kegiatan untuk mencapai tujuan tertentu. ${ }^{13}$ Pengertian ini masih general karena kesadaran belum difokuskan pada bidang tertentu. Ketika kesadaran tersebut difokuskan pada bidang tertentu, pengertiannya dapat dispesifikasi, seperti

\footnotetext{
${ }_{11}$ Al Maraghi, Tafsir Al Maraghi, jilid 1, Beirut, Dar al Kutub, tt, hal 67

${ }^{12}$ Tim Penyusun Kamus Pusat Pembinaan dan pengembangan bahasa Departemen Pendidikan dan Kebudayaan, Kamus Besar Bahasa Indonesia (Jakarta: Balai Pustaka, 1991), hlm. 859

${ }^{13}$ Mujamil Qomar, Kesadaran Pendidikan; suatu penentu keberhasilan pendidikan, (Jogjakarta: Arruz Media, 2012), hal. 120.
} 


\section{Kesadaran Pendidikan; Kunci Pengembangan Pendidikan Islam}

kesadaran pendidikan yang obyeknya sangat berbeda dengan misalnya kesadaran hukum. Kesadaran pendidikan merupakan kehadiran sikap mengetahui, memahami, menginsafi, dan menindak lanjuti proses pembimbingan untuk mengembangkan poyensi kemampuan seseorang menjadi sumber daya yang kuat (strong human resource).

Adapun kesadaran pendidikan didapatkan dalam beberapa macam:

1. Dari segi alur tahap pelaksanaan pendidikan, didapatkan beberapa kesadaran:

a. Kesadaran perencanaan.

Para pelaku pendidikan baik secara individu maupun secara institusional harus memiliki kesadaran perencanaan agar mereka dapat memproyeksikan dan memetakanaktifitas-aktifitas pendidikan kedepan dengan jelas, rinci, teratur, tersistem dan terukur. Selain itu juga dapat mematok target-target yang akan dicapai kedepan secara proporsional dan rasional diukur dari kondisi yang ada sekarang.

b. Kesadaran proses.

Semua pelaku pendidikan harus menyadari bahwa aktifitas pendidikan dan hasil-hasilnya dapat diwujudkan melalui suatu proses. Penanaman nilai pendidikan itu ada pada proses tersebut. Dengan memiliki keasdaran proses seseorang akan menempuh pendidikan mesti rela dan sabar menunggu proses berlangsung.

c. Kesadaran mutu. 


\section{Wafiyul Ahdi, SH., M.Pd.I.}

Semua pelaku pendidikan harus benar-benar insaf bahwa aktifitasaktifitas pendidikan seluruhnya dimaksudkan untuk mencapai mutu pendidikan.

d. Kesadaran kompetitif.

Kesadaran ini merupakan lanjutan dari keasadarn mutu. Setelah mutu pendidikan selesai, maka langkah berikutnya harus berupaya keras untuk membangun potensi yang lebih besar lagi sehingga mampu berkompetisi dengan pendidikan darimanapun di dunia ini. Kesadaran kompetitif diarahkan untuk mencapai keunggulan.

2. Dari segi sasaran bimbimgan.

a. Kesadaran keimanan dan ketakwaan.

Proses pendidikan di Indonesia harus diarahkan pada penguatan iman dan takwa. Kesadaran ini mendorong untuk mengimani dan mengakui adanya Tuhan Yang Maha Esa, dan memberikan ajaran-ajaran yang harus diamalkan.

b. Kesadaran intelektual.

semua pelaku pendidikan harus memiliki kesadaran intelektual untuk mengembangka kecerdasan diri sendiri maupun orang lain. Karena salah satu upaya pendidikan adalah memupuk, menyalurkan dan mengembangkan kecerdasan. Ketika kecerdasan itu berkembang maka ia mampu menangkap, 


\section{Kesadaran Pendidikan; Kunci Pengembangan Pendidikan Islam}

menampung, mengerti dan memahami informasi keilmuan yang diterima dari sumber-sumber pendidikan.

c. Kesadaran moral.

Kesadaran ini dibutuhkan karena moral yang baik dapat menghiasi kepribadian seseorang dengan tindakan-tindakan yang baik. Begitu juga sebaliknya. Moralitas bukan hanya melengkapi keimanan, ketakwaan dan intelektualitas seseorang, melainkan justru berpadu dengan tiga komponen tersebut. Jadi moralitas menempati posisi yang penting dalam proses pendidikan dan menjaga hasil-hasilnya.

d. Kesadaran ketrampilan.

Ketrampilan merupakan komponen yang penting yang harus dihasilkan oleh proses pendidikan. Karena ketrampilan dipandang sbagai refleksi tindak lanjut dari penguasaan pengetahuan dan pemahaman. Oleh karena itu diperlukan kesadaran ketrampilan bagi pelaku-pelaku pendidikan.

e. Kesadaran aplikatif.

Kesadaran aplikatif adalah kesadaran mengamalkan apa yang diperolehnya dalam proses pendidikan secara rutin dan kontinu.

f. Kesadaran integralistik.

Kesadaran integralistik adalah kesadaran untuk memadukan semua unsure kesadaran yang ada agar proses pendidikan yang dialaminya membentuk keoribadian yang utuh dan utama. 


\section{Wafiyul Ahdi, SH., M.Pd.I.}

3. Dari segi sudut pelaku.

a. Kesadaran autokritik.

Kesadaran ini ditujukan untuk diri sendiri agar menyadari kelemahan dan kekurangan yang ada pada dirinya dan membutuhkan perbaikanperbaikan dengan berusaha meningkatkan kualitas diri tanpa diperintah.

b. Kesadaran kolektif.

Kesadaran ini ditujukan kepada semua pihak yang terlibat dalam pendidikan secara masal agar mereka menyadari dan menginsafi kekurangan dan kelemahan masing-masing kemudian mereka mau merencanakan dan melaksanakan perbaikan-perbaikan dengan menghapus hal-hal yang menjadi kelemahan dan kekurangan mereka.

c. Kesadaran inter-kooperatif.

Kesadaran ini menghendaki adanya saling kerjasama antar semua pelaku pendidikan untuk mewujudkan keberhasilan pendidikan yang hakiki.

\section{Fungsi kesadaran pendidikan.}

Kesadaran memiliki arti yang penting dalam suatu kegiatan seeorang. Kesadaran menjadi intisari kerja. Seseorang baru dipandang bekerja kalau pekerjaan itu didasari kesadaran. Freire menyatakan bahwa tindakan dikatakan kerja bukan karena usaha fisik, melainkan karena kesadaran yang dimiliki oleh subyek dalam berusaha, memprogramkan tindakan, menciptakan alat, llu menggunakannya untuk 


\section{Kesadaran Pendidikan; Kunci Pengembangan Pendidikan Islam}

memediasi diri dengan obyek tindakannya, merumuskan tujuan, dan mengantisipasi masa depan. ${ }^{14}$

Adapun fungsi-fungsi kesadaran pendidikan dalam mewujudkan keberhasilan pendidikan, adalah sebegai berikut :

1. Menyadari dan melaksanakan tanggung jawab secara optimal.

Seseorang yang memiliki kesadaran pendidikan, biasanya mudah menyadari kemudian melaksanakan serangkaian kegiatan pendidikan yang menjadi tanggung jawabnya tanpa diperintah orang lain. Kesadaran dan aksi tersebut tum buh dari dalam dirinya sendiri sehingga merupakan kesadaran dan aksi yang alamiah (natural).

2. Menumbuhkan semangat belajar.

Orang yang memiliki kesadaran pendidikan selalu menempatkan pendidikan pada posisi yang penting dalam kehidupan dunia. Untuk mendapatkan pendidikan yang baik dibutuhkan kegiatan belajar dengan semangat yang tinggi. Oleh karena itu mereka dapat menumbuhkan semangat belajar baik belajar keilmuan maupun pengalaman pendidikan.

3. Mengoreksi kelemahan dan kekurangan diri sendiri (introspeksi).

Orang yang memiliki kesadaran pendidikan sepenuhnya memiliki kecenderungan kedalam lebih dahulu daripada keluar. Kecenderungan kedalam

\footnotetext{
${ }^{14}$ Paulo Freire, Politik Pendidikan Kebudayaan, Kekuasaan Dan Pembebasan, Terj. Agung Prihantoro Fuad Arif Fudiyartanto (Yogyakarta: READ [Research, Education, And Dialogue] Bekerjasama Dengan Pustaka Pelajar, 2002), Hal. 128.
} 


\section{Wafiyul Ahdi, SH., M.Pd.I.}

ini dimaksudkan memperhatikan, menelusuri, menilai dan mencermati kelemahan-kelemahan dan kekurangan mereka sendiri dalam ranah pendidikan.

4. Mengarahkan dan mengendalikan perilaku.

Kesadaran dapat memantau perilaku dan tindakan kita. Bahkan mengarahkan dan mengendalikannya sehingga tidak mudah terjebak dalam kesesatan.

5. Menumbuhkan semangat berprestasi.

Mereka yang memiliki kesadaran pendidikan cenderung memiliki semangat mengejar prestasi belajar.

6. Menumbuhkan mutu pendidikan.

Apabila semua pihak yang terkait dengan pendidikan memiliki kesadaran pendidikan, maka akan menimbulkan kualitas pendidikan sesuai yang diharapkan.

\section{Mekanisme membangun kesadaran pendidikan}

Kesadaran pendidikan merupakan kunci utama dalam mewujudkan kualitas dan keberhasilan pendidikan, baik pada domain kognitif, efektif, psikomotorik maupun mega kognitif. Denagn demikian kesadaran pendidikan memiliki atau menempati posisi poros diantara poros-poros pendidikan. Posisi ini menimbulkan kekuatan internal yang bersifat alamiyah dan serba menentukan aksi, reaksi, 
interaksi, dan respon terhadap aktifitas-aktifitas pendidikan sehari hari kendati terasa berat sekalipun.

Upaya membangun kesadaran pendidikan pada semua komponen pendidikan bisa dimulai dengan cara :

1. Menelusuri latar belakang peserta didik dari sisi psikologis, social dan ekonomi. Dari kegiatan ini akan diperoleh data yang memadai tentang kondisi mereka yang sesungguhnya. Dari situ kan ditemukan kecenderungan-kecenderungan yang menjadi potensi siswa/mahasiswa dan kemudian dianalisis untuk selanjutnya hasil analisa tersebut digunakan untuk memberikan pengarahan menuju tujuan pendidikan.

2. Menerapkan system pendidikan dan pembelajaran yang ketat pada semua perguruan tinggi. Dengan melakukan pengetatan system menjadikan para siswa/mahasiswa atau semua komponen pendidikan menjadi serius dan tidak meremehkan proses pendidikan yang dialaminya.

3. Meningkatkan kesadaran pendidikan pada kepala sekolah dan pimpinan perguruan tinggi sebagai manajer dan penentu kebijakan di institusi pendidikan mereka masing-masing.

4. Meningkatkan kesadaran pendidikan pada pemerintah melalui minimalisasi intervensi politik dalam pendidikan kecuali politik yang memberdayakan pendidikan itu sendiri, menempatkan pendidikan sebagai basis penyelesaian masalah-masalah kebangsaan, mengalokasikan dana yang besar untuk 


\section{Wafiyul Ahdi, SH., M.Pd.I.}

memaksimalkan pendidikan, serta memanfaatkan hasil-hasil pendidikan untuk mengakselerasi kemajuan sains dan teknologi.

5. Meningkatkan kesadaran pendidikan pada masyarakat sebagai pendukung keberhasilan proses pendidikan.

\section{Tahap-tahap membudayakan kesadaran pendidikan.}

Pembudayaan kesadaran pendidikan ini dapat ditempuh melalui tahapantahapan mulai dari uasaha yang paling mendasar hingga tahapan tindak lanjut yang bersifat mempertahankan dan mengembangkannya. Tahapan ini dapat memperkokoh kesadaran pendidikan meskipun membutuhkan waktu berproses yang cukup memadai. Tahapan tersebut meliputi :

1. Membentuk mindset.

Mindset ini mengarahkan dan meyakini bahwa kesadaran pendidikan memiliki potensi yang dahsyat dalam mewujudkan keberhasilan pendidikan. Mindset sangat berfungsi dalam mempengaruhi sikap, reaksi, respon, perilaku, pola piker, pola berinteraksi, dan pola kerja seseorang.

2. Mendemonstrasikan dan mendalami model sebgai contoh.

Tahap ini dilaksanakan dengan cara mengajukan seseorang sebagai model yang sukses lantaran kesadaran pendidikannya yang sangat kuat. Hal ini bisa menjadi inspirasi orang lain sehingga menimbulkan kesadaran pendidikan yang tinggi.

3. Melaksakan kesadaran pendidikan secara realistis dalam tugas/wilayah kerja masing-masing komponen masyarakat. 
4. Mempublikasikan dan mempopulerkan hasil dan dampak kesadaran pendidikan untuk memberikan pengaruh dalam membudayakan kesadaran pendidikan.

5. Melakukan evaluasi kritis terhadap semua tahapan-tahapan diatas, secara rasional, obyektif, kritis dan membandingkan dengan kondisi sebelumnya. Evaluasi ini untuk menjadi bahan pertimbangan menentukan dan menempuh langkah selanjutnya.

6. Melakukan tindak lanjut dari hasil evaluasi.

\section{Media untuk membudayakan pendidikan.}

Ada beberapa saluran yang dapat digunakan untuk membudayakan kesadaran pendidikan agar budaya tersebut cepat tumbuh dan berkembang sesuai dengan target yang diharapkan. Saluran tersebut berupa :

1. Kebijakan-kebijakan pendidikan melalui pendekatan birokrasi institusi pendidikan maupun pemerintah, karena kebijakan birokrasi ini bersifat mengikat pada lingkungan operasionalnya.

2. Pendidikan dan pengajaran.

3. Kegiatan pencerahan berupa ceramah ilmiyah, seminar, dialog, lokakarya, penataran dan penyuluhan.

4. Memanfaatkan berbagai media yang bisa diakses public. Baik media cetak, elektronik atau bahkan media social.

5. Melalui buku bacaan baik berupa buku majalah, bulletin, jurnal dan novel. 


\section{Wafiyul Ahdi, SH., M.Pd.I.}

6. Entertainment, baik film, sinetrin, drama, lagu-lagu, iklan dan sebagainya.

7. Dakwah berupa pengajian, khotbah, siraman rohani dan lain sebagainya.

\section{Kesadaran pendidikan dalam prespektif islam.}

Islam merupakan agama yang menuntut para pemeluknya untuk selalu belajar dan membuka wawasan baru sehingga tingkat keberagamaan seseorang menjadi lebih kokoh. Banyak perintah baik langsung (mantuq) maupun tidak langsung (mafhum) terkait ajakan untuk selalu menggali pengetahuan yang tersebar dalam ayat Al Qur'an maupun hadits Nabi. Bahkan Ayat Al Qur'an yang pertama turun sudah menunjukkan perintah membaca. Perintah untuk mencari pegetahuan melalui teks yang tersurat maupun yang tersirat. Atau yang disebutkan dalam QS At Taubah: 122

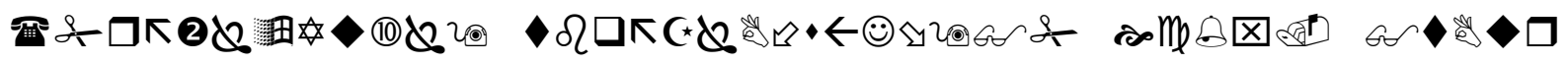

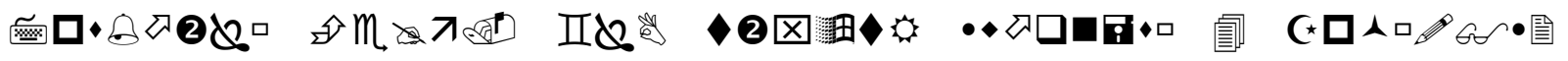

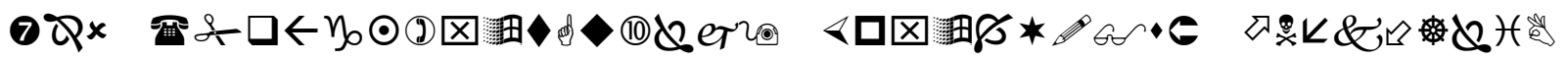

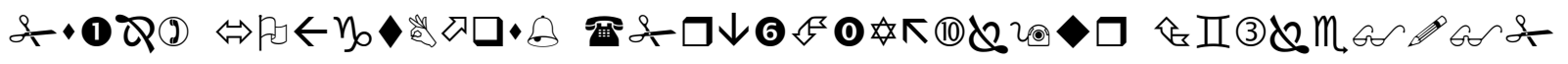 $\Leftrightarrow$ 的

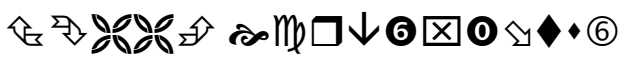

Artinya : Tidak sepatutnya bagi mukminin itu pergi semuanya (ke medan perang). mengapa tidak pergi dari tiap-tiap golongan di antara mereka beberapa orang untuk memperdalam pengetahuan mereka tentang agama dan untuk memberi peringatan kepada kaumnya apabila mereka telah kembali kepadanya, supaya mereka itu dapat menjaga dirinya.

Ayat tersebut menganjurkan untuk membagi kelompok masyarakat untuk tidak semuanya melaksanakan jihad tapi sebagian dari mereka hendaknya melakukan proses pembelajaran yang hasil pendidikan tersebut bisa digunakan 


\section{Kesadaran Pendidikan; Kunci Pengembangan Pendidikan Islam}

untuk membentuk dan menciptakan budaya yang unggul dalam masyarakat islam. Ini juga menunjukkan bahwa proses belajar itu tidak kalah utamanya dengan jihad fi sabilillh.

Banyak motivasi yang diberikan Rasululloh saw kepada umatnya agar selalu meningkatkan semangat belajar dengan iming-iming suatu pahala atau pujian-pujian tertentu bagi pelakunya dan ungkapan tentang keutamaan orang-orang yang menempuh proses pendidikan. Seperti dalam Hadits yang diriwayatkan oleh Imam Muslim dari Abi Hurairah :

$$
\text { من سلك طريقا يطلب فيه علما سلك الله به طريقا الى الجنة }
$$

Artinya: barang siapa menenpuh sebuah jalan yang disitu dia mencari ilmu pengetahuan, maka alloh menunjukkan jalan baginya menuju surga.

Atau sebuah hadits dengan sanad Mursal yang diriwayatkan Ad Darimi dan Ibnu Sinni :

مَنْ جَاءَهُ الموت و هو بطلب العلم ليحيِي به الاسلام فبينه وبين الانبياء فى الجنة درجة واحدة

Artinya: barang siapa meninggal dunia dalam keadaan brproses mencari ilmu untuk menghidupkan agama islam, maka di surga nanti, dia akan berada dalam satu tingkatan dengan para nabi.

Atau statemen Imam Asy Syafi'I : ${ }^{15}$

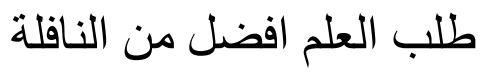

\footnotetext{
${ }^{15}$ Lihat Al Ghazali, Ihya ulumuddin, juz 1, Dar al Ihya' al kutub al arabiyyah, tt. Hal. 10
} 


\section{Wafiyul Ahdi, SH., M.Pd.I.}

Artinya : Belajar itu lebih utama daripada sholat sunat.

Begitu juga pendapat Abu Darda' ra. : 16

$$
\text { من راى ان الغدو فى طلب العلم ليس بجهاد فقد نقص فى رايه و عقله }
$$

Artinya : barang siapa menyangka bahwa berangkat mencari ilmu tidak dianggap sebagai sebuah bentuk jihad maka akal dan pendapatnya belum sempurna.

Dengan demikian ternyata banyak sekali motivasi-motivasi dari ayat $\mathrm{Al}$ Qur'an, Hadits maupun pendapat para ulama untuk selalu memiliki kesadaran menempuh pendidikan yang kemudian diwujudkan dengan melakukan proses belajar.

\section{Kesimpulan}

Dalam pemaparan diatas bisa disimpulkan bahwa :

1. Manusia secara naluriah memiliki potensi intelektual dalam bidang afektif, kognitif dan psikomotorik yang bisa dikembangkan untuk meningkatkan kualitasnya melalui proses pendidikan.

2. Macam-macam kesadaran pendidikan itu berupa :

Dari segi alur tahap pelaksanaan pendidikan, didapatkan beberapa kesadaran:
a. Kesadaran perencanaan.
b. Kesadaran proses.
c. Kesadaran mutu. 
d. Kesadaran kompetitif.

Dari segi sasaran bimbimgan.

a. Kesadaran keimanan dan ketakwaan.

b. Kesadaran intelektual.

c. Kesadaran moral.

d. Kesadaran ketrampilan.

e. Kesadaran aplikatif.

f. Kesadaran integralistik.

Dari segi sudut pelaku.
a. Kesadaran autokritik.
b. Kesadaran kolektif.
c. Kesadaran inter-kooperatif.

3. Fungsi kesadaran pendidikan :
a. Menyadari dan melaksanakan tanggung jawab secara optimal.
b. Menumbuhkan semangat belajar.
c. Mengoreksi kelemahan dan kekurangan diri sendiri (introspeksi).
d. Mengarahkan dan mengendalikan perilaku.
e. Menumbuhkan semangat berprestasi.
f. Menumbuhkan mutu pendidikan.

4. Mekanisme membudayakan kesadaran pendidikan : 


\section{Wafiyul Ahdi, SH., M.Pd.I.}

a. Menelusuri latar belakang peserta didik dari sisi psikologis, social dan ekonomi.

b. Menerapkan system pendidikan dan pembelajaran yang ketat pada semua perguruan tinggi.

c. Meningkatkan kesadaran pendidikan pada kepala sekolah dan pimpinan perguruan tinggi

d. Meningkatkan kesadaran pendidikan pada pemerintah.

e. Meningkatkan kesadaran pendidikan pada masyarakat sebagai pendukung keberhasilan proses pendidikan.

5. Tahap-tahap yang ditempuh untuk membudayakan kesadarn pendidikan :

a. Membentuk mindset.

b. Mendemonstrasikan dan mendalami model sebgai contoh.

c. Melaksakan kesadaran pendidikan secara realistis dalam tugas/wilayah kerja masing-masing komponen masyarakat.

d. Mempublikasikan dan mempopulerkan hasil dan dampak kesadaran pendidikan untuk memberikan pengaruh dalam membudayakan kesadaran pendidikan.

e. Melakukan evaluasi kritis terhadap semua tahapan-tahapan diatas, secara rasional, obyektif, kritis dan membandingkan dengan kondisi sebelumnya.

f. Melakukan tindak lanjut dari hasil evaluasi. 
6. Ada banyak motivasi untuk meningkatkan kesadaran pendidikan yang ersebar dalam Al Qur'an, hadits maupun pendapat para ulama. Diantaranya adalah QS At Taubah : 122, Hadits riwayat Imam Muslim dari Abi Hurairah, pendapat imam syafi'I dan sahabat Abu Darda' yang tersebut diatas. 


\section{Wafiyul Ahdi, SH., M.Pd.I.}

\section{DAFTAR PUSTAKA}

Al Ghazali, Ihya ulumuddin, juz 1, Dar al Ihya' al kutub al Arabiyyah

Al Maraghi, Tafsir Al Maraghi, jilid 1, Beirut, Dar al Kutub, tt.

M. Quraish Shihab, Wawasan Al qur'an : Tafsir Maudhu'I atas pelbagai persoalan umat, Bandung : Mizan, 1998.

Mujamil Qomar, Kesadaran Pendidikan; suatu penentu keberhasilan pendidikan, Jogjakarta: Arruz Media, 2012.

Musa Asy'ari, Manusia Pembentuk Kebudayaan dalam al Qur'an, Yogyakarta : Lembaga studi filsafat islam, 1992.

Sudirman, Ilmu Penidikan, Bandung : Remaja Rosdakarya, 1986

Tim Penyusun Kamus Pusat Pembinaan dan pengembangan bahasa Departemen Pendidikan dan Kebudayaan, Kamus Besar Bahasa Indonesia ,Jakarta: Balai Pustaka, 1991. 